\title{
INTERNAL AMBIENCE OF BEE COLONIES SUBMITTED TO STRENGTHENING MANAGEMENT BY ADDING BROODS
}

\author{
DANIEL DE F. BRASIL ${ }^{1}$, MICHELLE DE O. GUIMARÃES ${ }^{2}$, JOSÉ ANTONIO D. \\ BARBOSA FILHO ${ }^{3}$, BRENO M. FREITAS ${ }^{4}$
}

\begin{abstract}
This study aimed to investigate the ideal brood area to be introduced for strengthening Apis mellifera colonies, considering variations in the hive's internal ambience. Therefore, eight colonies were equipped with data loggers for recording variations in temperature and humidity inside the hives. Then, these colonies were split in four treatments involving the swapping of four, three, two and one brood comb between strong and weak colonies. Growth in the amount of brood and food stores to the four colony strengthening treatments was assessed counting the comb cells to record changes in the brood and food area. The colonies tended to restore their normal thermoregulation within four hours after they had been manipulated and the hive cover had been closed, which quickly increased brood area in the receiving colonies. Results showed that adding up to three brood combs constitute an important alternative for strengthening Apis mellifera colonies because it did not interfere with nest thermoregulation, speeded up population growth in weak colonies and did not affect the development of strong colonies.
\end{abstract}

KEYWORDS: colony homeostasis, thermal comfort, colony management.

\section{AMBIÊNCIA INTERNA DE COLÔNIAS DE ABELHAS SUBMETIDAS AO MANEJO DE FORTALECIMENTO POR ADIÇÃO DE CRIAS}

RESUMO: Objetivou-se com este trabalho investigar qual área de cria deve ser adicionada para o fortalecimento de colônias de Apis mellifera, considerando-se as variações na ambiência interna das colônias. Para tanto, oito colônias foram equipadas com data loggers para registro da temperatura e da umidade no interior das colmeias. Em seguida, essas colônias foram dispostas em quatro tratamentos, envolvendo a troca de quatro, três, dois e um quadro com crias, entre colônias fortes e fracas. A evolução da quantidade de crias e de alimento nos quatro tratamentos de fortalecimento das colônias foi quantificada pela contagem de alvéolos, avaliando-se mudanças na área ocupada por crias e alimento. As colônias tenderam a retornar sua termorregulação em até 4 horas após a manipulação e o fechamento da tampa das colmeias, o que aumentou rapidamente a área de cria das colônias receptoras. Os resultados apontaram que a adição de até três quadros com crias constituiu uma alternativa importante para o fortalecimento de colônias de Apis mellifera, pois não interferiu na termorregulação do ninho, acelerou o crescimento populacional das colônias fracas e não afetou o desenvolvimento das colônias doadoras.

PALAVRAS-CHAVE: homeostase apícola, conforto térmico, manejo de colônias.

\section{INTRODUCTION}

Beekeeping is an activity that has achieved great importance in the farming systems, since it presents an alternative employment and income for the farmer, besides being an activity of easy maintenance and low initial cost, compared to other activities in rural areas (OMRAN, 2011).

Despite of the diversity of potential products and services that can be exploited in beekeeping, only populated and well nourished colonies of Apis mellifera produce honey, pollen, beeswax, royal

\footnotetext{
${ }^{1}$ Universidade Federal do Ceará - UFC, Mestre em Ambiência Agrícola - Dep. Eng. Agrícola - Pici.

${ }^{2}$ Universidade Federal do Ceará - UFC, Mestre em Apicultura - Dep. Zootecnia - Pici.

${ }^{3}$ Prof. Dr., Universidade Federal do Ceará - UFC, Ambiência Agrícola - Dep. Eng. Agrícola - Pici.

${ }^{4}$ Prof. PhD., Universidade Federal do Ceará - UFC, Apicultura - Dep. Zootecnia - Pici.

Recebido pelo Conselho Editorial em: 11-10-2011

Aprovado pelo Conselho Editorial em: 5-5-2013
} 
jelly, propolis and apitoxin in economically viable quantities or perform pollination services satisfactorily (ENGELSDORP, 2010). Therefore, it is extremely important to promote the development and strengthening of the colonies before the period of production or flowering of crops (COELHO et al., 2008; EVANGELISTA-RODRIGUES et al., 2008), thus using management techniques, such as artificial feeding, queens exchanging and/or adding brood combs in weak colonies, among others (WIESE 2000). However, when you open and close a beehive, and especially when adding brood combs containing hundreds of larvae and pupae, the ideal ambience of an internal colony for good larval development, welfare of adults, ripening and storage of honey and pollen and durability of combs invariably is altered (MARDAN \& KEVAN, 2002).

Among other aspects, the ambience studies the types of managements in order to achieve the best animal welfare possible, where the decrease of stressors, such as direct incidence of sunlight and air and noise pollution, increases the final quality of the product and reduction of losses (BARBOSA FILHO, 2008). The research in beekeeping ambience shall analyze characteristics of the production environment in the zone of thermal comfort and physiological aspects of bees working in thermoregulation of the animal itself and the colony (BRASIL et al., 2011).

The bee is an ectothermic insect, but the colony works like a homeothermic organism, as it keeps the temperature in a narrow range of variation in the region of the nest (brood chamber) of 33 to $36^{\circ} \mathrm{C}$ (SHAW et al., 2011). The nest, central location of the colony, where the brood combs are located, cannot have large temperature variations, ranging up to 4 to $6^{\circ} \mathrm{C}$ for short periods of minutes to a few hours, and other parts of the hive can have greater fluctuation in temperature values (WINSTON, 2003).

There is evidence that the worker bees influence the humidity inside the hive. However, there are restrictions on the possible mechanisms of regulation, because the optimum humidity content (80\%) can vary at different locations of the nest. Humidity can also depend on external variables, such as availability of water used in evaporative cooling or the aggregate amount of water aggregated to the collected nectar, which jeopardizes even more, the regulation. In addition, there are tradeoffs with temperature regulation and respiratory gas exchange that can harm the establishment of ideal humidity levels, so it is argued that worker bees can only adjust the humidity within suboptimal limits of temperature ranging from 30 to $35^{\circ} \mathrm{C}$ (BARCHUK et al., 2002, WINSTON, 2003, HUMAN et al., 2006).

The thermoregulation of the colony is held by ergothermal efforts of worker bees, which shake their wings to promote ventilation, with consequent cooling, or vibrate the chest muscles to raise the temperature. Also, they regulate humidity and heat using other thermoregulatory procedures and humidifiers, such as the association of ventilation to the water collection and its distribution over the nest structures, lowering the temperature and increasing humidity (JONES \& OLDROYD, 2007; ELLIS, 2008; TAN et al., 2010).

The greater the disturbance to the colony, the greater the effort of thermoregulatory worker bees at the expense of time and resources that could be undertaken in activities of growth and production of the colony. In situations where the thermoregulatory effort required exceeds the capacity of worker bees, in the short or medium term, the colony may have developmental difficulties, may desert the hive or even die (MACIEIRA \& PRONI, 2004).

Based on the abovementioned, this study was conducted in order to investigate the brood area that should be added to the strengthening of colonies of Apis mellifera, considering the variations in the internal ambience of the colonies.

\section{MATERIAL AND METHODS}

The research was conducted in the apiary of the Bee Sector of the Federal University of Ceará (UFC), in the city of Fortaleza, state of Ceará - CE, Brazil, latitude $3^{\circ} 44^{\prime} \mathrm{S}$, longitude $38^{\circ} 33^{\prime} \mathrm{W}$ and altitude of $19.5 \mathrm{~m}$, in the period of July to September, 2010. According to Köppen classification, the 
climate is Aw'. It is a region that belongs to the tropical savanna climate, with average temperature of the coldest month greater than or equal to $18^{\circ} \mathrm{C}$.

Eight colonies belonging to the apiary of the Bee Sector of UFC were used in the experiment. The selected colonies were divided according to their population into two groups, the group of colonies that had been classified as donor of brood because it was stronger and the group of recipients considered weak. Treatment 1 involved the exchange of four combs without brood of a receptor colony $\mathrm{A}$ of four combs with broods a donor colony B. Treatments 2, 3 and 4 were conducted in the same manner, but three, two and one frame was exchanged among the colonies $\mathrm{C}$ and $\mathrm{D}, \mathrm{E}$ and $\mathrm{F}, \mathrm{G}$ and $\mathrm{H}$, respectively (Table 1).

The results were evaluated by qualitative analysis of pre- and post-intervention responses to strengthen the management of colonies, since qualitative research is often directed and does not prevent the researcher from employing the logic of scientific empiricism (suitable for clearly defined phenomena). Moreover, qualitative research does not seek to enumerate or measure events and generally does not employ statistical instruments for data analysis; it has a large focus of interest of a different perspective than the adopted by quantitative methods (NEVES, 1996).

In this study, colonies that had its occupied area with broods of less than $3,150 \mathrm{~cm}^{2}$, equivalent to a population equal or less than 30,000 bees were considered weak, and those that exceeded these values were considered strong (ELLIS \& DELAPLANE, 2008).

To determine the temperature and humidity in the internal environment of the colonies data loggers were used, model $\mathrm{HOBO}^{\circledR} \mathrm{U} 12-011$, which operated in a temperature record range of -20 to $70^{\circ} \mathrm{C}$ and 5 to $95 \%$ of relative humidity, with accuracy of $\pm 0.35^{\circ} \mathrm{C}$ and $\pm 2.5 \%$, respectively, with temperature resolution of $0.03^{\circ} \mathrm{C}$ and relative humidity of $0.03 \%$. The equipment was previously programmed to record every hour of the day; data recording started in the morning of the insertion of devices in the colonies. Data loggers remained in each colony for a period of 10 full days, time that the following steps of the bee life cycle may occur: egg laying until hatching (2-6 days), development of not operculated larvae to pupae (4 days) and emergence of adult bees (10 days) (RAMOS \& CARVALHO, 2007). Boxes external environment climate variables were recorded by the weather station of the Federal University of Ceará, about $250 \mathrm{~m}$ from the experiment area.

Before inserting the data logger inside the hive, visualization and previous classification of the combs were carried out; those combs with higher concentrations of brood and food were selected and removed from the nest. With the aid of a cutting tool, a portion of the honeycomb equal to the area of the data logger was removed, taking special attention not to remove large amounts of open and/or closed broods. Subsequently, the data logger was set between the wire frame and at the end of the procedure the hive was immediately closed. The methodology is repeated for all the other hives selected from each treatment (Figure 1).

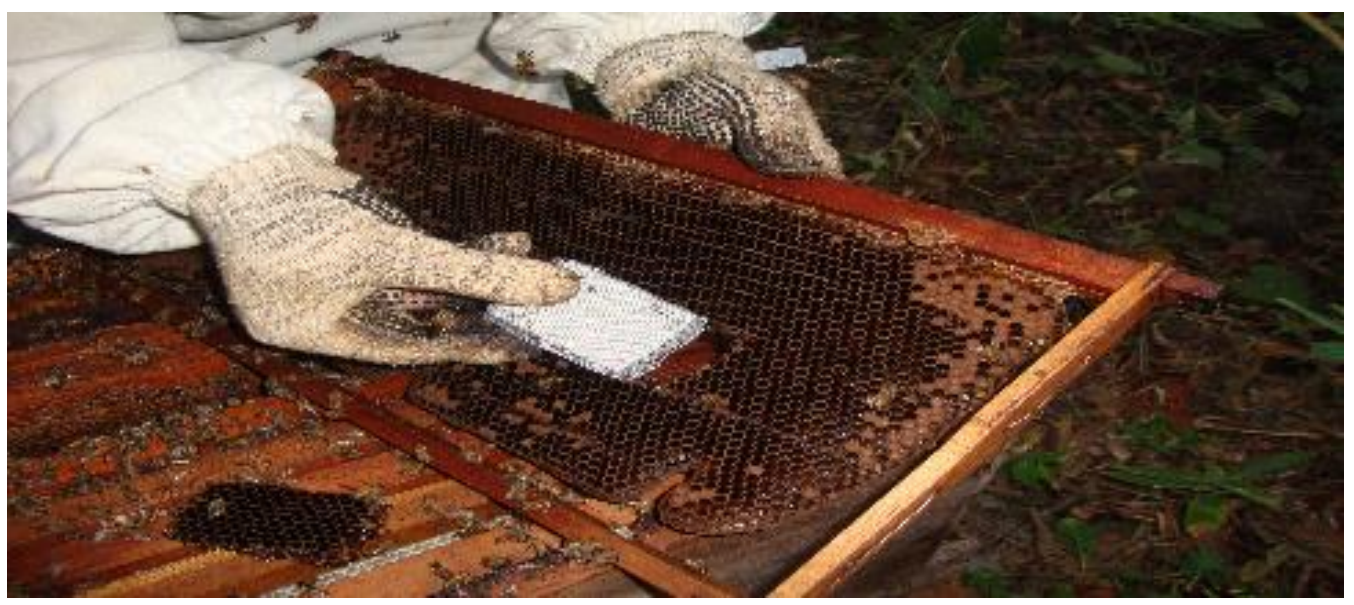

FIGURE 1. Data logger insertion in a brood comb. 
All alveoli of all combs were counted following an adaptation of the methodology of ALTIKRITY (1971) in order to follow the development of the colonies. The adaptation consisted of photographs of all overlapping combs of an image with virtual grids to obey the proportionality of $4 \mathrm{~cm}^{2}$, regardless of the distance or situation in which the photographs were taken at each stage of the experiment.

The counting of alveoli was performed using a free program called OdoPlus, which counts the clicks the mouse, where each click on a respective alveolus is counted, thereby leaving the measurements more accurate. At the end of counting, the number of alveoli was divided by fourteen, since each square of image contained, on average, fourteen alveoli. The number found after this division was subsequently multiplied by four, thus enabling the determination of the area occupied by brood or food (Figure 2).

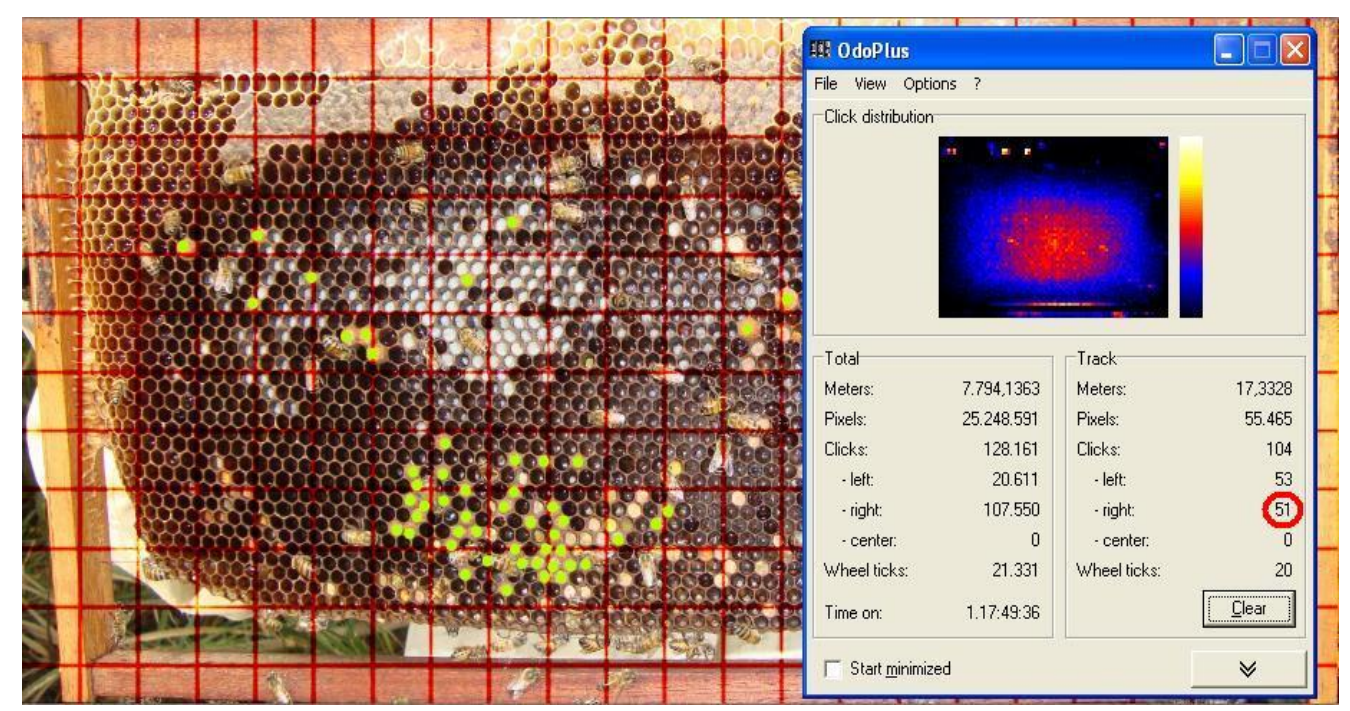

FIGURE 2. Alveoli counting system using a software which counts the mouse clicks and a software of image processing for the demarcation of the already recorded alveoli.

To follow the development of the colonies, photographs were taken on three separate occasions: minutes before placing the data logger, five days after the first photograph, which covered the management of exchanges of combs, and at the end of each treatment, on the tenth day.

During the period in which the boxes were with the data logger, there was no artificial feeding, so that the environmental conditions are compatible with those found in nature.

\section{RESULTS AND DISCUSSION}

The relative humidity of the indoor air of all colonies studied ranged from $56 \%$ (average relative humidity before exchanges) and $54 \%$ (average relative humidity after exchanges), which is below the average value of the external environment, which was $62 \%$. On the other hand, bees maintained temperature at $34^{\circ} \mathrm{C}$ on average for all colonies in the two stages of the experiment, while the external environment registered an average temperature of $28.3^{\circ} \mathrm{C}$. These results make it clear that the bees do not reach optimal levels of relative humidity inside the hive as well as they can do about the internal temperature of the colonies (BARCHUK et al., 2002, WINSTON, 2003, HUMAN et al., 2006).

Colony A, even receiving $1,650 \mathrm{~cm}^{2}$ of brood area (equivalent to four brood combs), suffered a sharp decrease in the total area of broods in the final experiment, reducing its initial area of $708 \mathrm{~cm}^{2}$ to just $382 \mathrm{~cm}^{2}$ (Table 1 ). 
TABLE 1. Evolution of brood areas for the different strengthen treatments.

\begin{tabular}{cccccc}
\hline Treatment & Box & Given/Received Combs & $\begin{array}{c}\text { Brood Areas at } \\
\text { the Beginning } \\
\left(\mathbf{c m}^{2}\right)\end{array}$ & $\begin{array}{c}\text { Given/Received } \\
\text { Broods }\end{array}$ & $\begin{array}{c}\text { Brood Areas at } \\
\text { the End }\left(\mathbf{c m}^{2}\right)\end{array}$ \\
\hline $\mathbf{1}$ & $\mathbf{A}$ & $(+4)$ & 708 & $(+) 1650$ & 382 \\
& $\mathbf{B}$ & $(-4)$ & 3612 & $(-) 1650$ & 2318 \\
$\mathbf{2}$ & $\mathbf{C}$ & $(+3)$ & 1154 & $(+) 1572$ & 2256 \\
& $\mathbf{D}$ & $(-3)$ & 4074 & $(-) 1572$ & 1094 \\
$\mathbf{3}$ & $\mathbf{E}$ & $(+2)$ & 2670 & $(+) 1242$ & 3372 \\
& $\mathbf{F}$ & $(-2)$ & 4466 & $(-) 1242$ & 4798 \\
& $\mathbf{G}$ & $(+1)$ & 1540 & $(+) 698$ & 354 \\
& $\mathbf{H}$ & $(-1)$ & 2974 & $(-) 698$ & 2852 \\
\hline
\end{tabular}

This major loss was caused by the abandonment of most of the eggs, larvae and pupae received, probably due to the small amount of food stored, the small population of existing worker bees and poor thermoregulation. These factors probably contributed to the inability of the colony to nourish and warm up properly all larvae and pupae, since at no time of the experiment the colony was able to maintain the heat balance of the nest (Figure 3). On the contrary, the temperature inside the beehive varied according to the external temperature and varied up to $8^{\circ} \mathrm{C}$, and for several moments it stayed out of range of the apiarian thermal comfort, which is of 33 to $36^{\circ} \mathrm{C}$, as defined by LOPES et al. (2011) and SHAW et al. (2011).

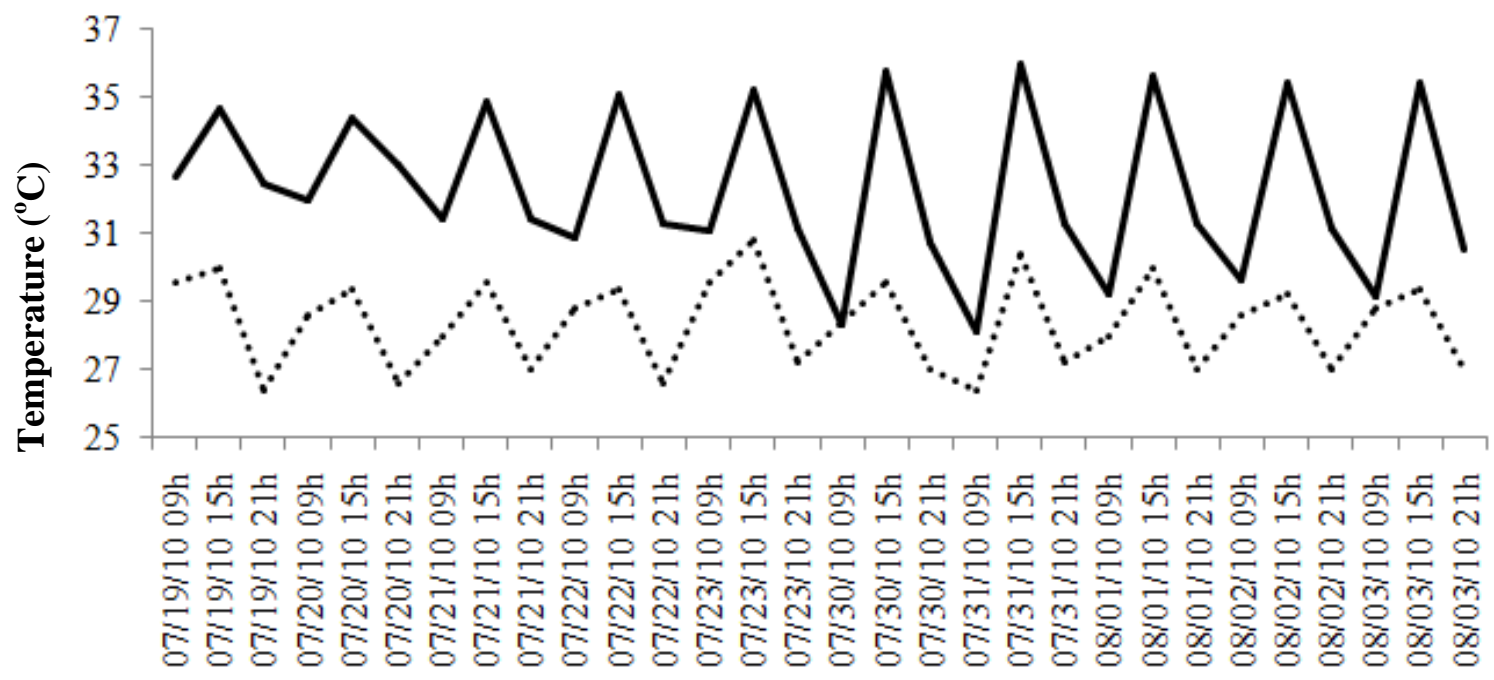

Days

\section{- Internal temperature $\quad \cdots$ External temperature}

FIGURE 3. Internal and external temperatures of colony A of the first treatment, which received four brood combs.

Colonies $\mathrm{B}, \mathrm{C}, \mathrm{E}, \mathrm{F}$ and $\mathrm{H}$ showed the expected population behavior for management strengthening. Those who gave brood combs were able immediately resume their growth, probably due to the wide availability of new spaces for laying eggs and rapid restoration of thermal equilibrium (Figure 4). On the other hand, receiving colonies showed significant increases in the number of brood at the end of the experiment (Table 1), since after succeeding with the restoration of optimal internal ambience of the hive, the worker bees ensured the survival of most of the brood added, and the resulting strengthening of the adult population in few days (Figure 4). Therefore, the 
climatic conditions inside the nest are critical for survival and good larval development (ALMEIDA, 2008).

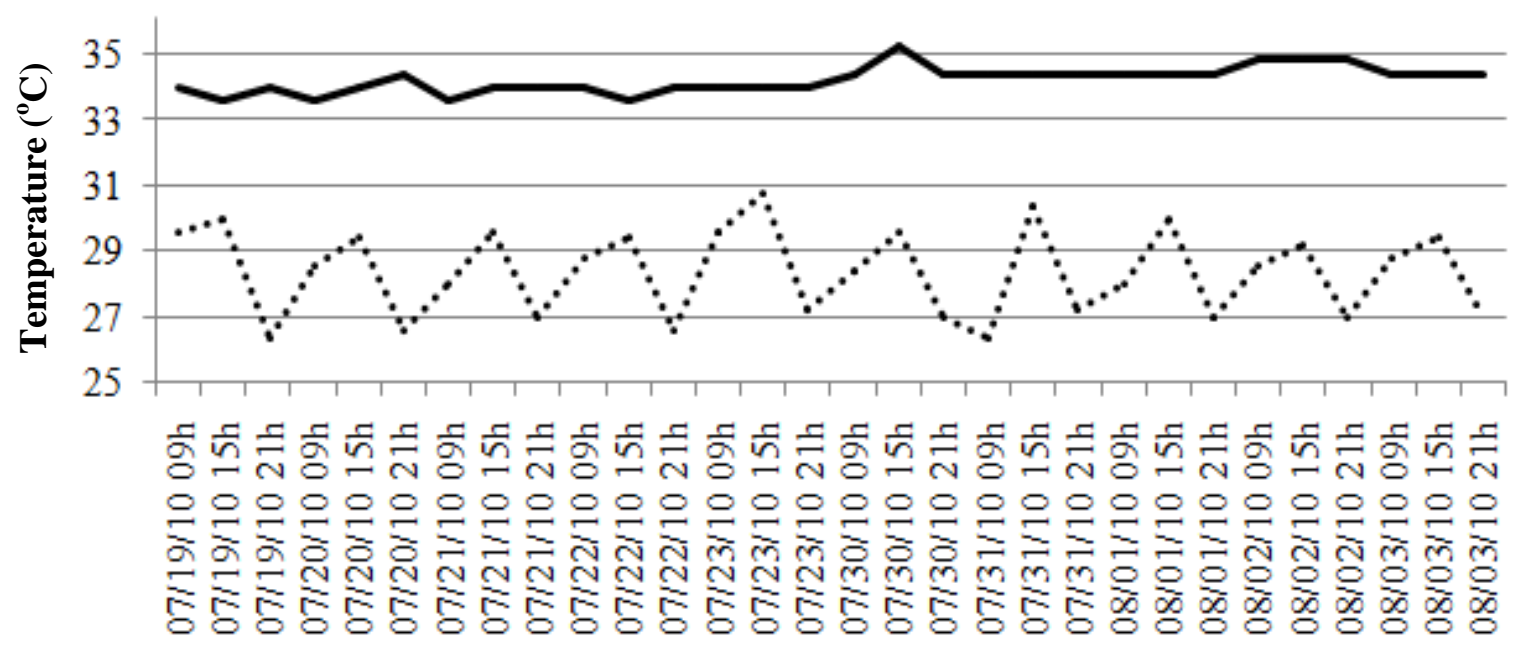

Days

Internal temperature $\quad \cdots \cdots$ External temperature

FIGURE 4. Internal ambience of colonies B, C, D, E, F, G and H compared witg the external environment temperature.

Colonies $\mathrm{D}$ and $\mathrm{G}$, which gave three brood combs and received one brood comb, respectively, unlike colonies $\mathrm{B}, \mathrm{C}, \mathrm{E}, \mathrm{F}$ and $\mathrm{H}$, did not resume its growth after giving or receiving the brood combs, even managing to keep the colony stable conditions for thermal comfort immediately after the manipulations. However, these reductions do not appear to be associated with the handling of removal or reception of broods, since the qualitative analysis of brood area of colonies shows that these began to fall immediately after the introduction of the data logger, five days before the comb exchange, continuing to decline until the end of treatment. According to GETZ et al. (1982), several factors, such as reduced food intake in the colony, the queen loss, preparations for swarming or to abandon the hive, among others, could cause a colony to reduce or suspend the posture abruptly, consequently leading to reduce the brood area. In fact, only colony $G$ showed queen cells (Figure 5), which princesses had emerged, and an apparent reduction in the adult population, suggesting that the colony had swarmed. Colony D did not show a plausible cause for the reduction of the area occupied with broods, while the others remained the same or increased these areas.

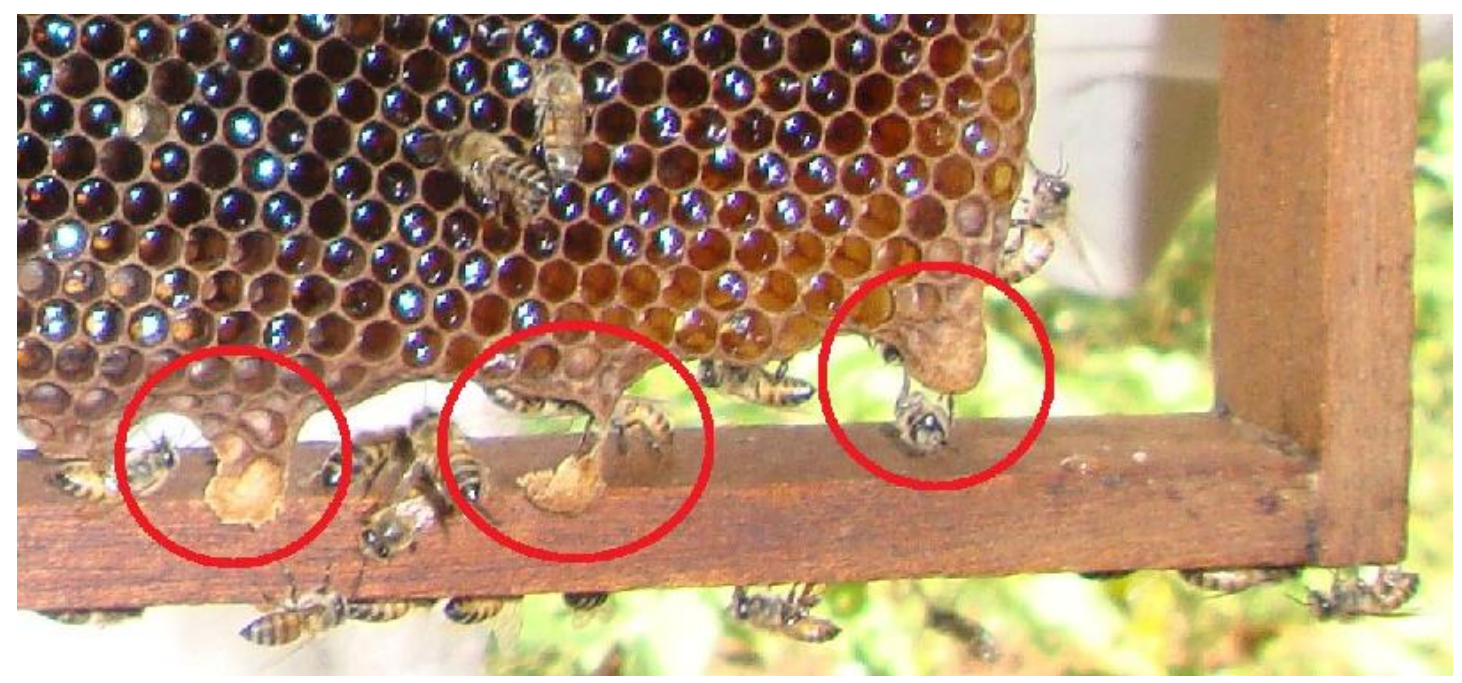

FIGURE 5. Presence of open, closed or under construction queen cells. 


\section{CONCLUSIONS}

Give or receive up to three brood combs was more suitable for the strengthening of colonies of Apis mellifera, which did not interfere in the nest thermoregulation, accelerating population growth of weak colonies without affecting the development of donor colonies.

\section{ACKNOWLEDGEMENTS}

The authors thank all those who directly or indirectly contributed to this study, especially those who are part of the Center for Studies in Agricultural Ambience and Animal Welfare (NEAMBE) and the Bee Research Group of the Federal University of Ceará. Breno M. Freitas thanks CNPq for the scholarship of Research Productivity (process number 305062/2007-7).

\section{REFERENCES}

ALMEIDA, G. F. Fatores que interferem no comportamento enxameatório de abelhas africanizadas. 2008. 120 f. Tese (Doutorado em Ciências)-Faculdade de Filosofia, Ciências e Letras de Ribeirão Preto, Universidade de São Paulo, Ribeirão Preto, 2008.

AL-TIKRITY,W.S. et al. New instrument for brood mea-surement in a honey-bee colony. American Bee Journal, Hamilton, v.111, n.1, p. 26, 1971.

BARBOSA FILHO, J.A.D. Caracterização quantiqualitativa das condições bioclimáticas e produtivas nas operações pré-abate de frangos de corte. 2008. $174 \mathrm{f}$. Tese (Doutorado em Física do Ambiente Agrícola) - Escola Superior de Agricultura "Luiz de Queiroz". Universidade de São Paulo, Piracicaba, 2008.

BARCHUK, A.R., BITONDI, M.M., SIMOES, Z.L. Effects of juvenile hormone and ecdysone on the timing of vitellogenin appearance in hemolymph of queen and worker pupae of Apis mellifera. Journal Insect Science, Wallingford, v. 2, p. 1, 2002.

BRASIL, D. F.; GUIMARAES, M. O. ; BARBOSA FILHO, J.A.D.; FREITAS, B. M. Análise da Ambiência interna de colônias de abelhas (Apis mellifera) submetidas ao manejo de fortalecimento. In: CONGRESSO BRASILEIRO DE ENGENHARIA AGRICOLA, 40.,2011, Cuiabá. Anais... Cuiabá: CONBEA, 2011.

COELHO, M. S.; SILVA, J. H. V.; OLIVEIRA, E. R. A.; ARAÚJO, J. A.; LIMA, M. R. Alimentos convencionais e alternativos para abelhas. Caatinga, Mossoró, v. 21, p. 01-09, 2008.

ELLIS, B. M. Homeostasis: Humidity and water relations in honeybees colonies (Apis mellifera). 2008. 126 f. Dissertation (Master's) - Faculty of Natural and agricultural Sciences, University of Pretoria, Pretoria, 2008.

ELLIS, J D; DELAPLANE, K (2008) Small hive beetle (Aethina tumida) oviposition behaviour in sealed brood cells with notes on the removal of the cell contents by European honey bees (Apis mellifera). Journal of Apicultural Research, London, v. 47, n. 3, p. 210-215.

EVANGELISTA-RODRIGUES, A.; GÓIS, G. C.; SILVA, C. M.; SOUZA, D. L.; SOUZA, D. N.; SILVA, P. C. C.; ALVES, E. L.; RODRIGUES, M. L. Desenvolvimento produtivo de colméias de abelhas Melipona scutellaris. Biotemas, Florianópolis, v. 21, p. 59-64, 2008.

GETZ, W.M.; BRÜCKNER, D.; PARISIAN, T.R. Kin structure and the swarming behavior of the honey bee Apis mellifera. Behavioral Ecology Sociobiology, New York, v. 10, p. 265-270.

HUMAN, H.; NICOLSON, S.W.; DIETEMANN, V. Do honeybees, Apis mellifera scutellata, regulate humidity in their nest? Naturwissenschaften, Berlin, v. 93, p. 397-401, 2006.

JONES, J. C.; OLDROYD, B.P. Nest thermoregulation in social insects. Advances in Insect Physiology, San Diego, v. 33, p. 153-191, 2007. 
LOPES, M. T. R.; BARBOSA, A. L.; VIEIRA NETO, J. M.; PEREIRA, F. M.; CAMARGO, R. C. R.; RIBEIRO, V. Q.; SOUZA, B. A. Alternativas de sombreamento para apiários. Pesquisa Agropecuária Tropical, Goiânia, v. 41, n. 3, p. 299-305, jul./set. 2011.

MACIEIRA, J.D.O.; PRONI, E.A. Capacidade de resistência a altas e baixas temperaturas em operárias de Scaptotrigona postica (Latreille) (Hymenoptera, Apidae) durante os períodos de verão e inverno. Revista Brasileira de Zoologia, São Paulo, v. 21, n.4, p. 893-896, 2004.

MARDAN, M.; P.G. KEVAN. Critical temperatures for survival of brood and adult workers of the giant honeybee Apis dorsata (Hymenoptera: Apidae). Apidologie, Versailles, v. 33, n. 3, p. 295301, 2002.

NEVES, J. L. Pesquisa qualitativa: características, usos e possibilidades. Caderno de Pesquisa em Administração, FEA-USP, São Paulo, v. 1. n. 3, 1996.

OMRAN, N.S.M., 2011. Wintering of Honeybee Colonies (Apis mellifera L.) by using a new technique during winter Season in Sohag Region, Egypt. Journal of Applied Science Research, Athens, v. 7, n. 2, p. 174-182, 2011.

RAMOS, J. M.; CARVALHO, N.C. Estudo morfológico e biológico das fases de desenvolvimento de apis mellifera. Revista Científica Eletrônica de Engenharia Florestal, v. 6, n. 10, ago. 2007.

SHAW, J. A.; NUGENT, P. W.; JOHNSON, J.; BROMENSHENK, J. J.; HENDERSON, C. B.; DEBNAM, S. "Long-wave infrared imaging for non-invasive beehive population assessment. Opticts Express, v. 19, p. 399-408, 2011.

TAN, K.; LI, H.; YANG, M.X.; HEPBURN, H.R.; RADLOFF, S.E. Wasp hawking induces endothermic heat production in guard bees. Journal of Insect Science, Wallingford, v. 10, p. 1-6, 2010.

ENGELSDORP, van D.; MEIXNER, M. D. A historical review of managed honey bee populations in Europe and the United States and the factors that may affect them. Journal of Invertebrate Pathology, San Diego, v. 103, p. S80-S95,2010. Supplement.

WIESE, H. Apicultura - novos tempos. Guaíba: Livraria Editora Agropecuária, 2000. 424p.

WINSTON, M. L. A Biologia da abelha. Tradução de Carlos A. Osowski. Porto Alegre: Editora Magister, 2003. 427 p. 